\title{
IMPACT OF CALIBRATION WATERSHED on RunOFF Model ACCURACY
}

\author{
V. Garg, I. Chaubey, B. E. Haggard
}

\begin{abstract}
Hydrologic/water-quality models often need calibration to minimize differences between observed and predicted watershed responses. Often the measured data from the watershed where the models are applied are not available. Under this condition, models are calibrated using data from a different watershed having similar land use, soil, and hydrologic conditions. However, if the watershed used for model calibration is not the same as the watershed where the model is applied for hydrologic/water-quality predictions, then differences in watershed characteristics may induce errors in model output. The objective of this study was to quantify the error in model predictions when the modeled watershed is not the calibrating watershed. The Agricultural Non-Point Source (AGNPS) model was used to quantify model errors using measured data from watersheds of varying sizes within the Little Washita Basin in Oklahoma. The study indicates that error in model outputs results when a watershed different than the one of interest is used for model calibration. A significant difference in prediction error was observed between scaling-up and scaling-down conditions with mean relative error of runoff prediction being $153 \%$ for the scaling-down condition and 69\% for the scaling-up condition. However, relative error of prediction showed no particular trend with the scaling ratios. A watershed having significantly higher or lower average curve number and slope condition was not a candidate watershed for calibrating the AGNPS model.
\end{abstract}

Keywords. AGNPS, Calibration, Hydrologic modeling, Rainfall-runoff modeling.

$\mathrm{H}$ ydrologic/water quality (H/WQ) models are increasingly used to assist with the analysis of data, test scientific hypotheses, improve the understanding of environmental processes and their interactions, and evaluate management scenarios (Grayson et al., 1992; Taylor et al., 1999). Integration of GIS, remote sensing, multiple databases, and visualization tools for extraction of the needed databases have further increased the use of the models by environmental researchers, resource planners, and decision makers (Jelinski et al., 1994; Stafford et al., 1994; Paniconi et al., 1999; Yang et al., 1999).

Rainfall runoff calculations are an important part of H/WQ simulation models because runoff erodes or dissolves non-point source pollutants and subsequently transports them. Runoff is a complex, temporally and spatially variable process, and is influenced by many factors. Field observations have shown that the major sources of heterogeneity leading to spatial differences in runoff are topography, soils, and space-time scales of precipitation (Loague, 1988; Kouwen and Garland, 1989; Wood et al., 1990; Beven and

Article was submitted for review in October 2002; approved for publication by the Soil \& Water Division of ASAE in June 2003. Presented at the 2002 ASAE Annual Meeting as Paper No. 022227.

Mention of a trade name or specific product does not constitute an endorsement by any agency contributing to this research.

The authors are Vijay Garg, ASAE Student Member, Graduate Research Assistant, and Indrajeet Chaubey, ASAE Member, Assistant Professor, Department of Biological and Agricultural Engineering, University of Arkansas, Fayetteville, Arkansas; and Brian E. Haggard, ASAE Member Engineer, Hydrologist, USDA-ARS Poultry Production and Product Safety Research Unit, Fayetteville, Arkansas. Corresponding author: Indrajeet Chaubey, Assistant Professor, 203 Engineering Hall, University of Arkansas, Fayetteville, AR 72701; phone: 479-575-4929; fax: 479-575-2846; e-mail: chaubey@uark.edu.
Wood, 1993; Ogden and Julien, 1994; Shah et al., 1996; Chaubey et al., 1999a, 1999b).

Watershed size also influences runoff because an ephemeral channel network might dominate hydrologic response on larger watersheds (Moore and Hutchinson, 1991). For example, in semiarid watersheds, runoff response became more nonlinear with increasing watershed size, with a critical transition between 0.37 to $0.60 \mathrm{~km}^{2}$ (Goodrich et al., 1997). The primary cause of this nonlinear response was attributed to increasing importance of ephemeral channel losses and partial storm area coverage. Therefore, H/WQ model calibration in smaller basins was not easily transferable to larger watersheds, and vice versa.

Depending on the formulation of the $\mathrm{H} / \mathrm{WQ}$ models, a number of parameters must be estimated to convert input rainfall into predicted runoff response of the watershed. Calibration is the process of adjusting these parameters so as to minimize the difference between observed and predicted watershed runoff response. H/WQ models are often calibrated using measured data from a different watershed than the one for which predictions are being made. Similarly, H/WQ models often are used to identify hydrologic "hot spots" within watersheds at intermediate points within the watershed, even though the model in use may not be calibrated using measured data from those points. Calibrating a model using data from a different watershed than the one of interest will introduce uncertainties in model predictions, when considering the complexity of runoff prediction. The objective of this study was to quantify the error in modeled runoff when a $\mathrm{H} / \mathrm{WQ}$ model was calibrated using data from a watershed having different size, topography, and land use characteristics. 


\section{Methods}

\section{Site DESCRIPTION}

This study was conducted in the Little Washita Basin, a tributary of the Washita River, in southwest Oklahoma. Five watersheds that included the Little Washita (LW), Cement (CM), Cyril (CR), SCS Pond 26 (SCS), and Boggy Creek (BC) were delineated from 7.5 minutes Digital Elevation Model (DEM) data (fig. 1). The nested watersheds were selected at established U.S. Geological Survey (USGS) stream gauging stations. Watershed areas ranged from 3.9 $\mathrm{km}^{2}$ (BC) to $625.0 \mathrm{~km}^{2}$ (LW) (table 1). Pasture was the dominant land use for all watersheds, except the SCS watershed where row crops dominated. Urban land use was a small component for all watersheds (less than $1.5 \%$ ). The area-weighted slope, calculated using slope and area of all cells within the watershed, varied among watersheds (table 1, fig. 2). The $\mathrm{BC}$ watershed had the greatest area-weighted slope (5.4\%), and the SCS watershed had the least area-weighted slope $(2.8 \%)$. Soil type on all the watersheds was silt except for the LW watershed, which had $2.9 \%$ area under sandy soil. The watersheds have a typical continental climate, characterized as moist sub-humid with average annual precipitation of $750 \mathrm{~mm}$. A detailed description of the soils, topography, geology, and climate of the watershed can be found in USDA-ARS (1991).

\section{Description OF THE AGNPS Model}

The Agricultural Non-Point Source (AGNPS) model version 5.0 (Young et al., 1987, 1994) was selected to quantify error in runoff prediction when the model is calibrated using data from a watershed different than one used for making watershed response predictions. AGNPS is an event-based model that simulates surface runoff, sediment, and nutrient transport from agricultural watersheds. Basic model components include hydrology, erosion, and sediment and chemical transport. In addition, the model considers point sources of water, sediment, nutrients, and chemical oxygen demand (COD) from animal feedlots and

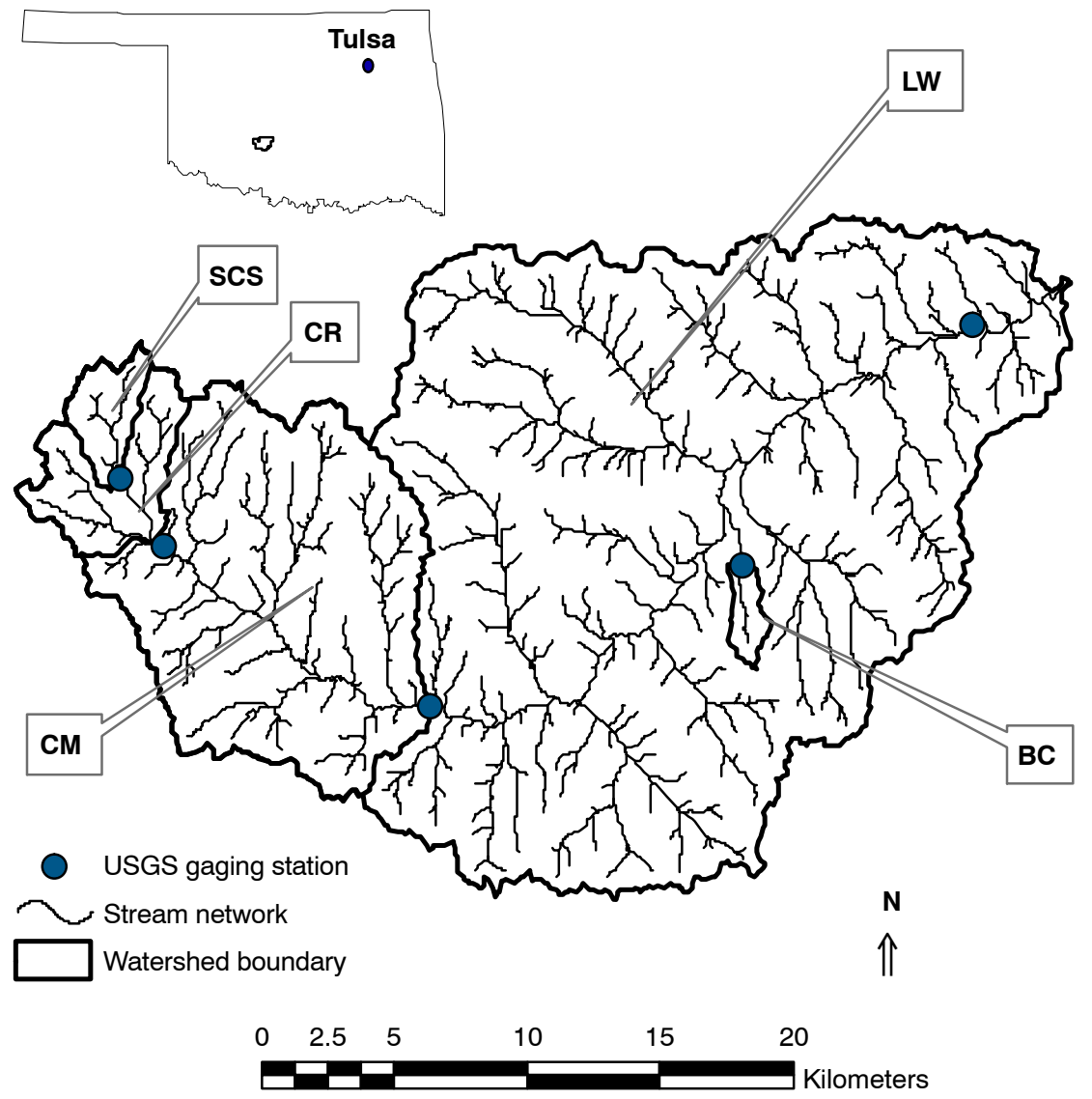

Figure 1. Location of the Little Washita basin and five nested watersheds.

Table 1. Characteristics of the five nested watersheds.

\begin{tabular}{|c|c|c|c|c|c|c|c|c|}
\hline \multirow[b]{2}{*}{ Watershed } & \multirow{2}{*}{$\begin{array}{c}\text { Area } \\
\left(\mathrm{km}^{2}\right)\end{array}$} & \multirow{2}{*}{$\begin{array}{c}\text { Area-Weighted } \\
\text { Slope }(\%)\end{array}$} & \multirow{2}{*}{$\begin{array}{l}\text { Area-Weighted } \\
\text { CN (std[a]) }\end{array}$} & \multicolumn{5}{|c|}{ Land Use (\%) } \\
\hline & & & & Forest & Pasture & Row Crops & Urban & Other \\
\hline LW & 625.0 & 4.65 & $71.9(2.8)$ & 11.0 & 64.7 & 22.3 & 0.9 & 1.2 \\
\hline $\mathrm{CM}$ & 161.1 & 3.91 & $73.0(2.6)$ & 7.7 & 56.1 & 33.8 & 1.2 & 1.2 \\
\hline $\mathrm{CR}$ & 30.6 & 3.27 & 73.9 (1.4) & 1.5 & 52.7 & 45.5 & 0.0 & 0.3 \\
\hline SCS & 9.6 & 2.84 & 74.0 (1.4) & 0.3 & 47.5 & 52.1 & 0.0 & 0.2 \\
\hline $\mathrm{BC}$ & 3.9 & 5.44 & $72.3(1.6)$ & 4.8 & 69.6 & 25.0 & 0.0 & 0.6 \\
\hline
\end{tabular}

[a] Standard deviation. 


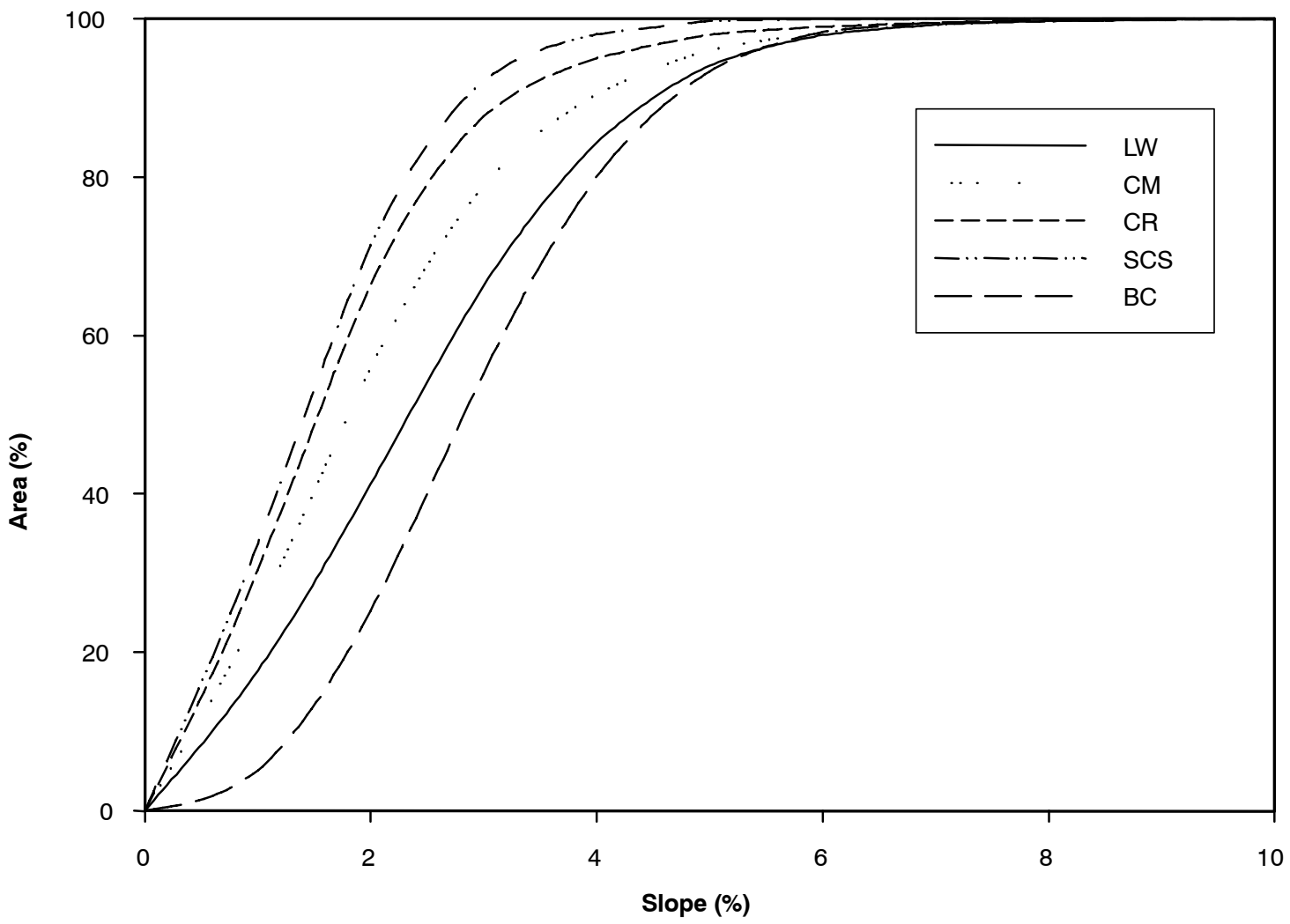

Figure 2. Slope distribution of the five nested watersheds within the Little Washita basin.

springs. Water impoundments, such as tile-outlet terraces, are considered as depositional areas of sediment and sediment-associated nutrients.

The model has the ability to predict water quality characteristics at intermediate points throughout the watershed network. This capability is based on implementation of "cells" within the model. Cells are uniform square areas subdividing the watershed, allowing analyses at any point within the watershed. All watershed characteristics (23 parameters or input values) are expressed at the cell level. Rainfall input is expressed at the watershed level.

The computation in AGNPS is completed in three stages. In the first stage, initial calculations are made for all cells in the watershed. These calculations include estimates for upland erosion, overland runoff volume, time until overland flow becomes concentrated, amount of soluble pollutants leaving the watershed via overland runoff, sediment and runoff leaving impoundment/terrace system, and pollutants coming from point source input such as feedlots. In the second stage, calculations are made for the runoff volume leaving the cells containing impoundments and the sediment yields of primary cells. In stage three, sediments and nutrients are routed through the rest of the watershed, and calculations are made to determine concentrated flow rates, channel transport capacity, and sediment and nutrient flow rates.

The AGNPS model calculates surface runoff using the USDA-NRCS curve number $(\mathrm{CN})$ method. The $\mathrm{CN}$ is a function of land use, soil type, and hydrologic conditions and is the most sensitive parameter in AGNPS (Chaubey et al., 1999b). Surface runoff calculated in each cell is routed through the watershed based on flow directions from one grid cell to the next until it reaches the drainage outlet. AGNPS does not attempt to model groundwater flux.

Results of AGNPS simulations in three small Mississippi watersheds indicated variable results because simulated total annual runoff varied from $65 \%$ to $151 \%$ of observed (Bingner et al., 1989). Panuska et al. (1991) used five rainfall-runoff events for catchment at the Agricultural Research Service's Cropping Systems and Water Quality Research Unit near Treynor, Iowa, to evaluate the terrain-enhanced version of the AGNPS model. Peak flow predictions ranged from $+25 \%$ to $-75 \%$. Sediment yield estimates seemed to follow peak flow predictions, attributed to the sediment movement algorithms in AGNPS driven by hydrology. Engel et al. (1993) compared the AGNPS, ANSWERS (Areal Nonpoint Source Watershed Environment Response Simulation), and SWAT (Soil and Water Assessment Tool) models using four rainfall runoff events on the same watershed; AGNPS and ANSWERS showed the best results when compared to measured values. AGNPS was validated using 50 rainfallrunoff events of 1981-1983 from two watersheds and five nested sub-watersheds in east central Illinois (Mitchell et al., 1992). The arithmetic mean of simulated runoff volume was $13 \mathrm{~mm}$ against the observed runoff mean of $7 \mathrm{~mm}$.

An ArcView GIS-based model interface (He et al., 2001) was used to prepare the AGNPS model input files. Basic input data used in the interface include soil, digital elevation model, land use/cover, and watershed boundaries. The grid cell size used to discretize the watershed was $0.174 \mathrm{~km}^{2}$.

\section{Description of The Rainfall Runoff Events ANd Data SET}

The USDA Agricultural Research Service (USDA-ARS) operates a network of 41 recording rain gauges, known as the 
Table 2. Observed rainfall and runoff of the five watersheds.

\begin{tabular}{ccccccc}
\hline \multirow{2}{*}{$\begin{array}{c}\text { Rainfall Date } \\
\text { (1999) }\end{array}$} & \multirow{2}{*}{$\begin{array}{c}\text { Rainfall } \\
(\mathrm{mm})\end{array}$} & \multicolumn{5}{c}{ Runoff from the Watershed $(\mathrm{mm})$} \\
\cline { 3 - 7 } & 47.5 & 1.07 & 1.86 & 0.85 & 1.30 & 1.13 \\
\hline 29-30 January & 47.5 & CR & SCS & BC \\
6 February & 25.1 & 0.99 & 2.84 & 1.33 & 8.30 & 0.45 \\
9 May & 30.3 & 1.37 & 4.02 & 0.76 & 1.45 & 0.13 \\
19-24 June & 62.5 & 2.31 & 2.60 & 1.93 & 1.46 & 1.65 \\
29-30 June & 29.2 & 1.13 & 2.76 & 2.62 & 3.96 & 0.32 \\
9-10 July & 22.5 & 0.68 & 1.71 & 0.75 & 1.52 & 0.05 \\
8-9 December & 55.4 & 1.95 & 2.97 & 1.91 & 2.62 & 1.77 \\
\hline
\end{tabular}

Micronet, within and near the Little Washita basin. Measured data from the Micronet were used to derive average rainfall for each event. A total of seven rainfall events in 1999 (29-30 January, 6 February, 9 May, 19-24 June, 29-30 June, 9-10 July, and 8-9 December) were selected for this study. In the subsequent discussion, each rainfall is identified by the first date of the event. The criterion used in selecting rainfall dates was the magnitude of the rainfall. Only relatively larger rainfall events $(>20 \mathrm{~mm})$ were selected because of their importance in erosion and transport of sediment and nutrients from agricultural watersheds (table 2). The variability in the rainfall amount observed by the Micronet stations was quantified using the standard error (SE) between observed and average rainfall and the coefficient of variation (CV) (table 4).

Daily average stream flow data were obtained for each watershed from U.S. Geological Survey (USGS) stream gauging stations (http://waterdata.usgs.gov/nwis/annual). Streamflow was separated into base flow and surface runoff components using a hydrograph separation program, Base Flow Index (BFI) (Wahl and Wahl, 1995). The BFI model identifies the minimum daily mean flow in a 5-day timeframe, and minima less than $90 \%$ of adjacent minimum are defined as turning points (Wahl and Wahl, 1988; Wahl and Tortorelli, 1997). Surface runoff (table 2) was estimated as the difference between total stream flow and base flow, where the base flow was estimated by drawing straight lines between turning points of the hydrograph. Rainfall values for five days preceding each rainfall event were considered to derive antecedent moisture conditions used in $\mathrm{CN}$ calculations (Haan et al., 1993).

\section{Estimation of Model Output Errors Due to Calibrating Watershed Characteristics}

The only watershed response modeled was runoff volume because no measured water quality data for any of the watersheds were available. The AGNPS model was calibrated for each rainfall event by adjusting the $\mathrm{CN}$ to minimize differences between observed and predicted runoff. Because AGNPS is a distributed parameter model, each cell may have a different $\mathrm{CN}$ depending on soil and land use characteristics. This poses a special problem for calibration because infinite sets of $\mathrm{CN}$ may exist that give the same runoff outputs. To overcome this problem, individual $\mathrm{CN}$ values of all the cells of the watershed were changed either upward or downward at the same time in the increment of one until predicted runoff volume equaled observed runoff volume.

The AGNPS model can be used to obtain watershed response at the outlet as well as at any other point within the watershed. The model was calibrated for one watershed at a time and used to predict runoff at the other four watersheds.
Therefore, the model produced one prediction on the calibrated watershed and four predictions with remaining watersheds. This process was repeated for each of the seven rainfall events. The predicted runoff values for other watersheds were then compared with the measured runoff to quantify model output uncertainty. The output uncertainty was quantitatively described as percent relative error (RE):

$$
\mathrm{RE}=\frac{|\mathrm{P}-\mathrm{O}|}{\mathrm{O}} \times 100
$$

where $\mathrm{P}$ is the predicted runoff value, and $\mathrm{O}$ is the observed runoff value. RE values were not calculated for the BC watershed for one rainfall event when observed runoff was $0.05 \mathrm{~mm}$ (table 2) because observed runoff became zero when the runoff value was converted into inches (up to two significant digits), as runoff calculations in the AGNPS model are done in inches up to two significant digits.

\section{RESUlTS AND DiscusSiON}

\section{Model Error Due to Calibrating Watershed Size}

Often, H/WQ models are calibrated on watersheds smaller or larger than the watershed where model predictions are desired; therefore, two types of scaling conditions were defined. Scaling-up defined a condition where the calibrating watershed was smaller in size than the predicting watershed. Scaling-down referred to a condition where the calibrating watershed was larger in size than the predicting watershed. The scaling ratio was defined as the larger watershed area divided by the smaller watershed area, which was always greater than one.

From the five watersheds of this study, there were ten scaling-up and ten scaling-down conditions. RE values corresponding to seven rainfall events were calculated for each scaling condition (fig. 3). A significant difference between RE of scaling-up and scaling-down conditions was observed using a paired two-tailed t test $(\mathrm{p}<0.05)$ (Sheskin, 2000). However, no particular trend in RE values of runoff for scaling-up or scaling-down conditions was observed $\left(\mathrm{R}^{2}=\right.$ $0.0)$.

Accuracy of results can be increased in the AGNPS model by reducing cell size (Young et al., 1987, 1994). A smaller cell size is recommended for smaller watersheds compared to larger watersheds (Young et al., 1987, 1994). This suggests that smaller ratios of cell size to watershed size $\left(R_{\text {cell }}\right.$ to watershed) will improve model accuracy. Only one cell size $\left(0.174 \mathrm{~km}^{2}\right)$ was used in this study, resulting in a smaller $\mathrm{R}_{\text {cell }}$ to watershed ratio for larger watersheds and scaling-up conditions. A smaller $\mathrm{R}_{\text {cell to watershed }}$ ratio resulted in lower $\mathrm{RE}$ for scaling-up conditions. The scaling-down conditions had a significantly greater RE $($ mean $=153 \%)$ than the scaling-up conditions $($ mean $=69 \%)($ paired one-tailed $t-t e s t, p<0.05)$ (Sheskin, 2000).

\section{RE in Modeled Outputs Due to Calibrating WATERShed ChARACTERISTICS}

For each watershed model prediction there existed seven RE values associated with seven rainfall events with respect to each calibrating watershed. Fisher's LSD tests (Sheskin, 2000) were conducted to assess if the calibrating watershed characteristics had significant impact on runoff RE. Critical difference $\left(\mathrm{CD}_{\mathrm{LSD}}\right)$ levels were computed to compare the 

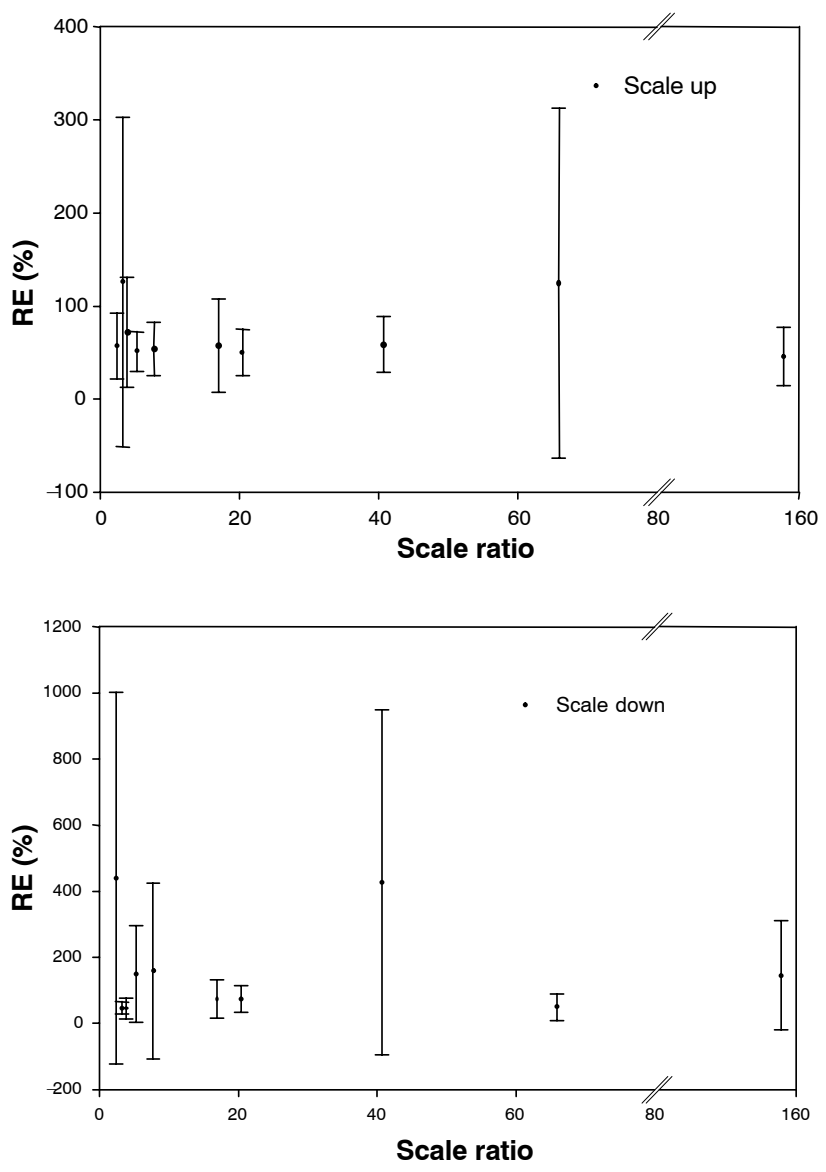

Figure 3. Average relative error (RE) of model runoff predictions of all the rainfall events for scaling-up and scaling-down conditions.

Table 3. Mean relative error of seven rainfall events for studied watershed of interest when calibrated with different watersheds. For each watershed of interest, statistical analysis (Fisher's LSD test at 0.05 level) was performed.

\begin{tabular}{cccccc}
\hline \multirow{2}{*}{$\begin{array}{c}\text { Calibrating } \\
\text { Watershed }\end{array}$} & LW & CM & CR & SCS & BC \\
\cline { 2 - 6 } & $0 \mathrm{a}^{[\mathrm{a}]}$ & $45 \mathrm{n}$ & $74 \mathrm{pq}$ & $50 \mathrm{y}$ & $145 \mathrm{uv}$ \\
$\mathrm{LW}$ & $72 \mathrm{ab}$ & $3 \mathrm{~m}$ & $150 \mathrm{q}$ & $74 \mathrm{y}$ & $427 \mathrm{uv}$ \\
$\mathrm{CM}$ & $50 \mathrm{ab}$ & $51 \mathrm{n}$ & $0 \mathrm{p}$ & $47 \mathrm{y}$ & $160 \mathrm{uv}$ \\
CR & $124 \mathrm{~b}$ & $57 \mathrm{n}$ & $126 \mathrm{q}$ & $0 \mathrm{x}$ & $440 \mathrm{v}$ \\
SCS & $45 \mathrm{ab}$ & $59 \mathrm{n}$ & $54 \mathrm{pq}$ & $57 \mathrm{y}$ & $0 \mathrm{u}$ \\
BC &
\end{tabular}

[a] The same letters within a column indicate that watersheds used in the model calibration do not give significantly different prediction of runoff volume RE $(\mathrm{p}<0.05)$.

minimum difference required for two means to differ significantly $(\mathrm{p}=0.05)$. Table 3 summarizes the statistical analyses results of Fisher's LSD test for each watershed, along with the average RE values in predicted runoff for seven rainfall events. The results within each column indicate that a significantly larger RE in predicted runoff occurred when the AGNPS model was calibrated using data from a watershed other than the one used for making runoff predictions. The AGNPS-predicted runoff had significantly different RE for the CM and SCS watersheds when the model was calibrated using data from any other watershed (table 3 , columns 3 and 5). This indicates that when making runoff predictions for the CM and SCS watersheds, the data from only these two watersheds should be used for model calibration. For the CR

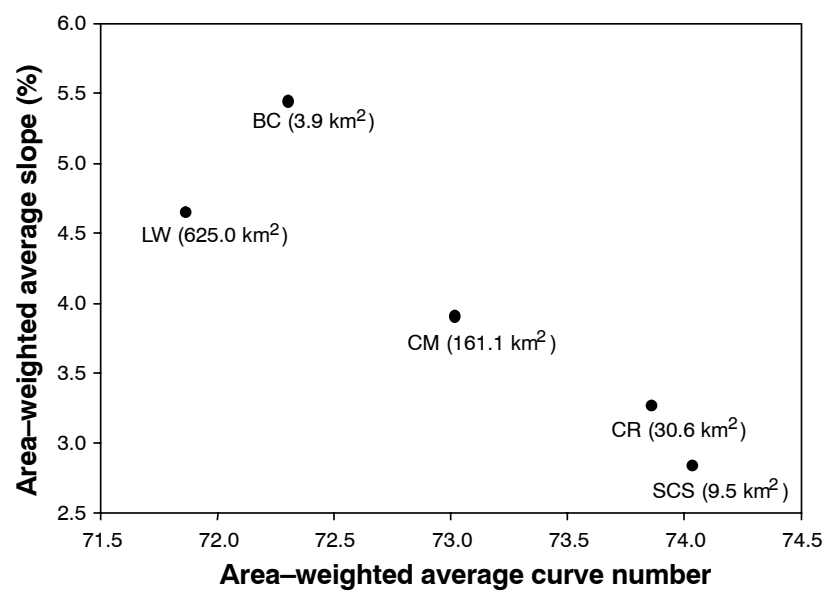

Figure 4. Area, land use, and slope of the five nested watersheds in the Little Washita basin (parentheses denote watershed area in $\mathbf{k m}^{2}$ ).

watershed, predicted runoff had a significantly different RE when the model was calibrated using data from the $\mathrm{CM}$ and SCS watersheds. For the LW and BC watersheds, predicted runoff had significantly different RE when the model was calibrated using data from the SCS watershed.

The SCS watershed did not work satisfactorily as a calibrating watershed for the AGNPS model (table 3, row 5). The reason may be that the SCS watershed had the highest area-weighted curve number and the lowest area-weighted average slope among the five watersheds (fig. 4).

Model-predicted runoff RE for the CM watershed was also significantly different when the model was calibrated using data from any other watershed (table 3), even though the $\mathrm{CM}$ watershed had characteristics (slope and $\mathrm{CN}$ values) similar to many other watersheds. The reason could be the difference between the trend of model runoff prediction and observed runoff response. For five out of seven rainfall events, observed runoff was highest from the $\mathrm{CM}$ watershed. The other two rainfall events (6 February and 29 June) produced the second highest response on the $\mathrm{CM}$ watershed (table 2). However, the CM watershed had the third highest value of area-weighted average $\mathrm{CN}$, which resulted in the third highest value of runoff prediction for this watershed and not the highest value. The CN method used in the AGNPS model does not take into account variability of rainfall and topography, although these factors may influence runoff. Some of the computer models, such as EPIC (Erosion-Productivity Impact Calculator; Williams et al., 1982) and SWRRB (Simulator for Water Resources in Rural Basins; Williams et al., 1985), incorporated adjustment in the CN value based on the slope. The absence of $\mathrm{CN}$ adjustment in AGNPS based on slope might be the cause of the CM watershed having significantly different RE when calibrated with any other watershed.

The effect of rainfall variability on model runoff prediction was examined by arranging the model prediction values for each rainfall event. Twenty RE values of runoff (table 4) were calculated for each rainfall event (four for each watershed $\times$ five watersheds in the study). For rainfall values of 22.5 to $30.3 \mathrm{~mm}$, spatial variability of rainfall was higher $(\mathrm{CV}>30)$ compared to rainfall values from 47.5 to $62.5 \mathrm{~mm}$ $(\mathrm{CV}<30)$ (table 4). Similarly, mean RE of modeled runoff volumes was also higher for lower rainfall values compared to higher rainfall (table 4). These results provide further 
Table 4. Statistics of rainfall events based on data from 41 rain gauges of the watershed along with relative error (RE) of runoff for each rainfall event.

\begin{tabular}{ccccccc}
\hline \multicolumn{3}{c}{ Rainfall Events } & & \multicolumn{2}{c}{ RE of Runoff } \\
\cline { 1 - 3 } \cline { 7 - 8 } $\begin{array}{c}\text { Date } \\
(1999)\end{array}$ & $\begin{array}{c}\text { Average } \\
(\mathrm{mm})\end{array}$ & $\begin{array}{c}\text { SE } \\
(\mathrm{mm})\end{array}$ & $\begin{array}{c}\text { CV } \\
(\%)\end{array}$ & & $\begin{array}{c}\text { Mean } \\
(\%)\end{array}$ & $\begin{array}{c}\text { CV } \\
(\%)\end{array}$ \\
\hline 9 July & 22.5 & 16.4 & 73.1 & & $58.3^{[\mathrm{a}]}$ & $53.2^{[\mathrm{a}]}$ \\
6 February & 25.1 & 9.5 & 37.6 & & 190.1 & 147.8 \\
29 June & 29.2 & 16.5 & 56.3 & & 204.9 & 146.6 \\
9 May & 30.3 & 9.6 & 31.6 & & 188.6 & 153.2 \\
29 January & 47.5 & 5.6 & 11.8 & & 43.7 & 81.0 \\
8 December & 55.4 & 9.5 & 17.2 & & 29.7 & 66.9 \\
19 June & 62.5 & 14.3 & 22.8 & & 45.2 & 67.7 \\
\hline
\end{tabular}

[a] Based on 16 observations.

evidence that spatial variability of rainfall increases the RE of runoff volume predictions of AGNPS and must be considered to minimize errors in watershed runoff response predictions.

\section{SuMmaRY AND CONCluSIONS}

The effect of calibrating watershed characteristics on runoff predictions using the AGNPS model was assessed. Five nested watersheds of the Little Washita basin with measured rainfall and runoff data from seven rainfall events were used in this study. Calibrating watersheds were found to have a statistically significant effect on model predicted runoff RE for a watershed. The AGNPS model prediction for all five watersheds based on four different calibrating watersheds showed that at least one calibrating watershed had significantly different RE of runoff than the control. The watershed with the lowest value of weighted area average slope and highest curve number was not found suitable for calibrating any other watershed. The mean of 20 values of RE of runoff prediction (five watersheds $\times$ four predictions for four calibrating watersheds) from a rainfall event in general followed the spatial variability of rainfall. Spatial variability of rainfall for less than $30.3 \mathrm{~mm}$ was more $(\mathrm{CV}>30)$ compared to rainfall values greater than $47.5 \mathrm{~mm}(\mathrm{CV}<30)$. A significant difference between RE of scaling-up and scaling-down conditions was observed, but the RE values showed no particular trend with the scaling-up or scalingdown ratio $\left(\mathrm{R}^{2}=0.0\right)$. Greater $\mathrm{RE}$ was observed for the scaling-down condition (153\%) compared to the scaling-up condition (69\%).

The results of this study indicate that every effort must be made to calibrate the model using data from the same watershed where the model is used to make runoff response predictions. A significant error in model predictions can be expected if the model is calibrated using data from a watershed having different topographic, soil, and land use characteristics than the watershed of interest. In general, when the calibrating and predicting watersheds are different, the model calibration based on a smaller watershed results in lesser RE than model calibration based on a larger watershed.

\section{ACKNOWLEDGEMENTS}

Funding for this study was provided by the Arkansas Agricultural Experiment Station. Data for this study were obtained from the USDA Meteorological Micronetwork, the USDA-ARS Grazing Lands, and the USGS National Water Information System Database.

\section{REFERENCES}

Beven, K. J., and E. F. Wood. 1993. Flow routing and the hydrological response of channel networks. In Channel Network Hydrology, 99. K. J. Beven and M. J. Kirkby, eds. Chichester, U.K.: John Wiley.

Bingner, R. L., C. E. Murphree, and C. K. Mutchler. 1989. Comparison of sediment yield models on various watersheds in Mississippi. Trans. ASAE 32(2): 529-534.

Chaubey, I., C. T. Haan, J. M. Salisbury, and S. Grunwald. 1999a. Quantifying model output uncertainty due to spatial variability of rainfall. J. American Water Resources Assoc. 35(5): 1113-1123.

Chaubey, I., C. T. Haan, J. M. Salisbury, and S. Grunwald. 1999b. Uncertainty in the model parameters due to spatial variability of rainfall. J. Hydrology 220: 48-61.

Engel, B. A., R. Srinivasan, J. Arnold, C. Rewerts, and S. J. Brown. 1993. Non-point source (NPS) pollution modeling using models integrated with geographic information system (GIS). Water Sci. Tech. 28(3-5): 685-690.

Goodrich, D. C., L. J. Lane, R. M. Shillito, and S. N. Miller. 1997. Linearity of basin response as a function of scale in a semiarid watershed. Water Resources Research 33(12): 2951-2965.

Grayson, R. B., I. D. Moore, and T. A. McMahon. 1992. Physically based hydrologic modeling: 2. Is the concept realistic? Water Resources Research 26(10): 2659-2666.

Haan, C. T., B. J. Barfield, and J. C. Hayes. 1993. Design Hydrology and Sedimentology for Small Catchments. San Diego, Cal.: Academic Press.

He, C., C. Shi, C. Yang, and B. P. Agosti. 2001. A window-based GIS-AGNPS interface. J. American Water Resources Assoc. 37(2): 395-406.

Jelinski, D. E., M. F. Goodchild, and L. T. Steyaert. 1994. Multiple roles for GIS in global change research: Towards a research agenda. In Environmental Information Management and Analysis: Ecosystem to Global Scales, 40-56. W. K. Michener et al., eds. Bristol, Pa.: Taylor and Francis.

Kouwen, N., and G. Garland. 1989. Resolution consideration in using radar data for flood forecasting. Canadian J. Civil Eng. 16: 279-289.

Loague, K. M. 1988. Impact of rainfall and soil hydraulic property information on runoff predictions at the hillslope scale. Water Resources Research 24(9): 1501-1510.

Mitchell, J. K., B. A. Engel, R. Srinivasan, and S. S. Y. Wang. 1992. Validation of AGNPS for small watersheds using an integrated AGNPS/GIS system. ASAE Paper No. 922532. St. Joseph, Mich.: ASAE.

Moore, I. D., and M. F. Hutchinson. 1991. Spatial extension of hydrologic process modeling. In Proc. International Hydrology and Water Resources Symposium, 803-808. Perth, Australia: Institute of. Engineers.

Ogden, F. L., and P. Y. Julien. 1994. Runoff model sensitivity to radar rainfall resolution. J. Hydrology 158: 1-18.

Paniconi, C., S. Kleinfeldt, J. Deckmyn, and A. Giacomelli. 1999. Integrating GIS and data visualization tool for distributed hydrologic modeling. Trans. in GIS 3(2): 97-118.

Panuska, J. C., I. D. Moore, and L. A. Kramer. 1991. Terrain analysis: Integration into the agricultural non-point source (AGNPS) pollution model. J. Soil Water Conserv. 1: 59-64.

Shah, S. M. S., P. E. O’Connell, and J. R. M. Hosking. 1996. Modeling the effects of spatial variability in rainfall on catchment response: 2 . Experiments with distributed and lumped models. J. Hydrology 175: 89-111.

Sheskin, D. J. 2000. Handbook of Parametric and Nonparametric Statistical Procedures. Boca Raton, Fla.: Chapman \& Hall/CRC.

Stafford, S. G., J. W. Brunt, and W. K. Michener. 1994. Integration of scientific information management and environmental research. In Environmental Information Management and 
Analysis: Ecosystem to Global Scales, 1-19. W. K. Michener et al., eds. Bristol, Pa.: Taylor and Francis.

Taylor, K., G. Walker, and D. Abel. 1999. A framework for model integration in spatial decision support systems. Int. J. Geo. Info. Science 13(6): 533-555.

USDA-ARS. 1991. Hydrology of the Little Washita River Watershed, Oklahoma. Washington, D.C.: USDA Agricultural Research Service Press.

Wahl, K. L., and R. L. Tortorelli. 1997. Changes in flow in the Beaver-North Canadian River Basin upstream from Canton Lake, Western Oklahoma. USGS Water Resources Investigations Report 96-4304. Washington, D.C.: U.S. Geological Survey.

Wahl, K. L., and T. L. Wahl. 1988. Effects of regional ground-water level declines on streamflow in the Oklahoma panhandle. In Proc. Water-Use Data for Water Resources Management, 239-249. Middleburg, Va.: American Water Resources Association.

Wahl, K. L., and T. L. Wahl. 1995. Determining the flow of Comal Springs at New Braunfels, Texas. In Texas Water '95, 77-86. Reston, Va.: American Society of Civil Engineers.
Williams, J. R., P. T. Dyke, and C. A. Jones. 1982. EPIC - A model for assessing the effects of erosion on soil productivity. In Proc. 3 rd Int. Conf. on State-of-the-Art in Ecological Modeling, 553-572. Fort Collins, Colo., Colorado State University, International Society for Ecological Modeling.

Williams, J. R., A. D. Nicks, and J. G. Arnold. 1985. SWRRB, A simulator for water resources in rural basins. ASCE Hydraulics $J$. 111(6): 970-986.

Wood. E. F., M. Sivapalan, and K. J. Beven. 1990. Similarity and scale in catchment storm response Rev. Geophys. 28(1): 1-18.

Yang, M. D., C. J. Merry, and R. M. Sykes. 1999. Integration of water quality modeling, remote sensing, and GIS. J. American Water Resources Assoc. 35(2): 253-264.

Young, R. A., C. A. Onstad, D. D. Bosch, and W. P. Anderson. 1987. AGNPS, agricultural non-point source pollution model A watershed analysis tool. USDA Conservation Research Report 35:1-80. Washington, D.C.: USDA.

Young, R. A., C. A. Onstad, D. D. Bosch, and W. P. Anderson. 1994. Agricultural Non-Point Source Pollution Model: AGNPS User's Guide. Morris, Minn.: USDA-ARS. 
